\title{
MANAGEMENT (ADMINISTRATIVE) ACTIVITY OF THE CONTROLLING AUTHORITIES IN THE AREA OF TAXATION: ESSENCE AND TYPES
}

\author{
Olha Tylchyk', Yurii Riabchenko², Oleksandr Popivniak ${ }^{3}$
}

\begin{abstract}
The innovation of conceptual provisions of the administrative law doctrine that are based on the priority of rights, freedoms, legitimate interests of an individual, service orientation of the public administration authorities' performance affects the essence of the controlling authorities' management (administrative) activity in the area of taxation and requires its fundamental upgrade. Drafting of theoretical provisions as to the essence and the types of the controlling authorities' management (administrative) activity in the area of taxation should be based on a profound theoretical and legal analysis of the existing concepts and doctrines and their comparison with the current developments in the public administration authorities' performance that carry out similar activities. In addition, it's reasonable to highlight the issues of legal regulation of the relations with respect to the controlling authorities' management (administrative) activity carried out in the area of taxation. The research objective is to substantiate the theoretical background of the controlling authorities' management (administrative) activity in the area of taxation set out in the form of a list of the substantive characteristics of such activity, the provisions that reflect its peculiarities, as well as the systematization of the lines and types of such activity. The object of the research is the social relations of a public-law nature, related to the activities of the controlling authorities in the area of taxation. The contemporary concepts and doctrines developed by the scientists through critical thinking constitute the theoretical basis of the scientific analysis. This article explores the scientific papers related to the issues of public administration, administrative law, and administrative activity. System-based approach constitutes the methodology of the scientific analysis which made it possible to single out the elements of the administrative activity system, to reveal their content and to take into account their specific features when determining the nature of the controlling authorities' management (administrative) activity in the area of taxation. The result of this research is the theory that reveals the current essence of the specified activity and its lines. This article places emphasis on the existence of public and service component of the specified activity.
\end{abstract}

Key words: management activity, administrative activity, controlling authorities, taxation, lines of activity.

JEL Classification: K34, H71

\section{Introduction}

The relevance of the problem as to determining the essence of the administrative activity of the controlling authorities in the area of taxation is driven by fundamental innovation of the administrative law doctrine, rethinking of their tasks from the viewpoint of compliance with the tasks of the service that performs a service function. This problem is directly related to the appropriate implementation of the provision of Article 1 of the Constitution of Ukraine which codifies that Ukraine is a sovereign and independent, democratic, social and rule-of-law State (Constitution of Ukraine

\footnotetext{
Corresponding author:

${ }^{1}$ National University of the State Fiscal Service of Ukraine, Ukraine. E-mail: o.v.tilchik@ukr.net

${ }^{2}$ National University of the State Fiscal Service of Ukraine, Ukraine.

E-mail: 0971713748@ukr.net

${ }^{3}$ National University of the State Fiscal Service of Ukraine, Ukraine.

E-mail: 797oliv@gmail.com
}

as of the $28^{\text {th }}$ of June 1996) (Konstytutsiia Ukrainy vid 28.06.1996 - in Ukrainian). The specified constitutional legal provision stipulates for all government authorities performance effectiveness, and especially those targeted at ensuring national financial security, generation of the revenue part of the National Budget and the budgets at all levels, raising money for the state special-purpose funds as the essentials for further social and economic growth of Ukraine.

In applicable legislation, terms "revenue and duties authorities", "fiscal service", "controlling authority" are applied to indicate the subject of the state control in 
the area of taxation. Thus, Article 283 of the Code of Administrative Court Procedure (hereinafter referred to as the CACP) determines the peculiarities of the proceedings on the cases if they are brought before the court by the revenue and duties authorities (on making amendments in the Code of Commercial Procedure of Ukraine, the Civil Procedure Code of Ukraine, the Code of Administrative Court Procedure of Ukraine and in the other legislative acts: Law of Ukraine as of the $13^{\text {th }}$ of March 2012) (Pro vnesenniazmin do Hospodarskoho protsesualnoho kodeksu Ukrainy, Tsyvilnoho protsesualnoho kodeksu Ukrainy, Kodeksu administrativnoho sudochynstva Ukrainy ta inshykh zakonodavchykh aktiv: Zakon Ukrainy vid 03.10. 2017 - in Ukrainian). Term "revenue and duties authority" is applied in the Customs Code of Ukraine (Mytnyi kodeks Ukrainy vid 13.03.2012 in Ukrainian). Term "controlling authority" has been applied in the Tax Code of Ukraine (Podatkovyi kodeks Ukrainy (red. 01/01/2017): Zakon Ukrainy vid, 02.12.2010 - in Ukrainian), and term "fiscal service" has been applied in Resolution of the Cabinet of Ministers of Ukraine as of the $21^{\text {st }}$ of May 2014 Ref. No. 236 "On the State Fiscal Service of Ukraine” (Pro Derzhavnu fiskalnu sluzhbu Ukrainy: Postanova Kabinetu Ministriv Ukrainy vid 05/21/2014 - in Ukrainian).

The stated above indicates a need to unify the terms that are used in the applicable law and specify the subject authorized to exercise the state control in the area of taxation. Taking into account the indicated above, application of the term "controlling authority in the area of taxation" does not contravene the allocable law but allows to define the subject of the state control in the specified area and its place within the system of the government authorities, in particular, belonging to the structure of the State Fiscal Service of Ukraine (hereinafter - the SFS).

In the course of the SFS offices' tasks performance the management (administrative) activity holds a special place. The activity above seeks to solve not just managerial tasks. It is also related to the implementation of the law-enforcement function of the state. At the same time, administrative legal proceedings perform a dual function: on the one hand, it serves as a legal institution intended to protect violated rights, freedoms, legal interests of individuals and legal entities-taxpayers from offences against law by the SFS offices (SFS offices' employees) when implementing the administrative activity and on the other hand, a form for implementation of the government task by the SFS offices as to protection of the interests of the state through filing a petition in the administrative court in the cases set forth in Article 283, Part 1, the CACP.

\section{Theoretical basis}

In the scientific research of administrative law and process, the issue related to the essence of the controlling authorities' administrative activities in the area of taxation has not yet been the subject of a separate scientific inquiry. The researchers at the level of the thesis for a doctor's degree analysed the issues related to the State Tax Service management (Bandurka, 2005), administrative and legal status of the Head within the State Tax Service offices (Holovach, 2011), the issues of taxation system establishment, administration and reform (Uhrovetskyi, 2009). In the context of the topic, which is being researched, the monograph by V. V. Konopliov attracts interest with a focus on management decisions within the internal affairs offices (Konoplyov, 2006).

Among the scientific research, we should indicate the presence of such direction of theoretical analysis as a problem of tax disputes settlement (Y. A. Usenko (Usenko, 2011), V. V. Tylchyk (Tylchyk, 2011) and others). Many scientific papers are dedicated to research of the separate aspects as to definition and implementation of the legal status by the revenue and duties authorities (O. P. Dzisiak (Dzisiak, 2002), A. M. Kulish (Kulish, 2003) and others). Recently the research direction of the essence of information relations (I. V. Aristova, K. I. Bieliakov (Bieliakov,2008), A. M. Novytskyi (Novytskyi, 2012) and others) have been developing dynamically.

Notice that, in fact, the term "administrative activity" in modern administrative legal science hasn't been used extensively enough in view of the following: first, use of other more fixed terms such as "public administration", "executive and administrative activity", "administrativelegal influence"; second, lack of clear approaches to definition of the executive authority's administrative activity, its tasks, principles, difference from the other types of activities; third, different understanding of the balance of such categories as "function of the executive authority", "executive authority's line of activity", "executive authority's type of activity"; fourth, absence of direct legislative framework for administrative activity as an independent line of the activity conducted by the executive authorities (Redkous, 2008).

According to the Concept of Public Administration Reform in Ukraine, codified in Decree of the President of Ukraine "On the Measures to Implement the Concept of Public Administration Reform in Ukraine" (Pro zakhody shchodo vprovadzhennia Kontseptsii administrativnoi reformy v Ukraini: Ukaz Prezydenta Ukrainy vid 22.07.1998 - in Ukrainian), its implementation is underway in several lines. By V. V. Halunkonotes, these are such lines as:

- drafting of a new legal framework to regulate public administration in Ukraine, including information provision of this activity; establishment of the institutes of new organizationalstructuresandinstruments to carryoutpublic administration; staffing of a new public administration system; strengthening and setting up of a new financial and economic framework for public administration 
functioning, including administrative activity in the area of tax collection; scientific and information support of public administration system, development of the mechanisms for scientific and information monitoring of its functioning (Halunko, 2011).

Nevertheless, such important regulatory legal acts to regulate the administrative activity as Administrative Procedural Code of Ukraine, Information Code of Ukraine, and a number of other regulations haven't been adopted yet. Their effect should be aimed at optimization of the administrative authorities' operation procedures at regional and local levels, avoidance of overlaps of the functions between the regional offices of central executive authorities and local executive authorities, as well as improvement of public administration institutions interaction with the citizens.

Such foreign and domestic scientists focused their attention on the issue of the government authorities' administrative activity in the area of theory of state and law, the theory of public administration, administrative law and process:

V. B. Averianov (Administrative activity) (Administratyvna diialnist: M. V. Kovaliv, S. R. Kisil, D.P. Kataianovtain, 2009-in Ukrainian), O. O. Bandurka (Bandurka, 2004), D. M. Bakhrakh (Bakhrakh, 2000), I.L.Bachylo (Bachylo, 2001), Y.P.Bytiak (Bytiak, 1999), I. P. Holosnichenko, Y. Y. Kondratiev (Holosnichenko ta in., 2005), L. V. Koval (Koval, 1998), A. P. Korenev (Internal affairs offices' administrative activity) (Admynystratyvnaia deiatelnost orhanov vnutrennykh del. Chast obshchaia. Pod red. A. P. Koreneva, 2003 in Russian), V. Y. Malynovskyi (Malynovskyi, 2005), Y. M. Moiseiev, V. I. Olefir, Y. I. Rymarenko (Internal affairs offices' administrative (law enforcement) activity) (Administratyvna (politseiska) diialnist orhaniv vnutrishnikh sprav (Zahalna chastyna): Yu. I. Rymarenko, Ye. M. Moiseiev, V. I. Olefir, 2008 in Ukrainian), V. D. Pryimachenko (Pryimachenko, 2007), Y.A. Tykhomyrov (Teremetskyi, 2012) and others.

\section{Results}

Within the scope of the subject presented, it is reasonable to analyse, in the first instance, the essence of administrative activity and the approaches to its definition.

By administrative activity L. V. Koval (Koval, 1998) means publication of regulatory and individual acts. I. P. Holosnichenko, Y. Y. Kondratiev define administrative activity as the activity of government executive authorities aimed at ensuring the protection of civil rights, public safety, detection, suspension, and prevention of offenses (Holosnichenko ta in., 2005). A. P. Korenev (Internal affairs offices' administrative activity) (Admynystratyvnaia deiatelnost orhanov vnutrennykh del. Chast obshchaia. pod red, A. P. Koreneva, 2003 - in Russian) characterizes administrative activity as the implementation of functions as to practical ensuring of personal safety of citizens, protection of public order and public security. Y. A. Tikhomirov (Tykhomyrov, 2005) holds a different view and gives the following definition of administrative activity: it is public administration in the narrow sense, that is, the activity of government authorities, executiveadministrative authorities of the state as to exercise of executive power at its different levels.

The scientists in their scientific research define the essence of administrative activity mainly in logical and conceptual connection with the subject of its implementation, i.e. by the State Penitentiary Service of Ukraine (R. V. Aliiev (Aliiev, 2009)), the internal affairs offices (D. V. Holoborodko (Holoborodko, 2009), S. M. Husarov (Husarov, 2009), V. O. Zarosylo (Zarosylo, 2002)), the State Border Guard Service of Ukraine (B. M. Marchenko (Marchenko, 2009), L. V. Servatiuk (Servatiuk, 2008)), the Ukraine's State Tax Service offices (T. O. Mazelyk (Matselyk, 2005)), the customs authorities (D. V. Pryimachenko (Pryimachenko, 2007)). According to the subject of research, it is reasonable to point out the scientific paper of V. B. Marchenko, dedicated to the administrative and legal regulation in the area of tax collection (Marchenko, 2009.) A number of scientists used to analyse administrative activity in the context of police law (Y. I. Rymarenko, Y.M.Moiseiev, V.I.Olefirand others(Internalaffairsoffices' administrative (law enforcement) activity) (Administratyvna (politseiska) diialnist orhaniv vnutrishnikh sprav (Zahalna chastyna): Yu. I. Rymarenko, Ye. M. Moiseiev, V. I. Olefir, 2008 - in Ukrainian)).

The concept of administrative activity is considered both in general and applied aspect. The most common definition of the executive authority's administrative activity was formulated by D. N. Bakhrach: "Administrative activity is a systematic, continuous organization seeking to preserve the social system, its strengthening and development" (Bakhrakh, 2000).

It is appropriate to agree with the viewpoint of N. I. Zolotariova who used to recognize a broader meaning of "government authority's administrative activity" concept of as compared to executive power the concept. Thus, administrative activity by the subject of its implementation does not coincide with executive power, which is exercised only by the authorities of this branch of the government and special institutions delegated with powers to perform the functions of the executive authorities. Administrative activity as a management activity, regulated by the administrative law provisions, is carried out not just by the executive authorities. Organizational legal relations govern the norms of the administrative law and exist within the scope of the activities performed by the courts, the prosecutor's office, the secretariat of the Parliament of Ukraine (the Verkhovna Rada of Ukraine) or the Presidential Administration, where administrative functions are performed (Zolotariova, 2011). 
Nevertheless, the specific character of the subject of administrative activity affects its features, determined by the legal status of the corresponding subjects, the tasks and the functions they perform. This raises the question of clarification of the essence of the controlling authorities' administrative activity in the area of taxation.

Public administration science defines administrative activity as the executive and administrative activity of public authorities governed by the norms of administrative law and aimed at the implementation of rights and freedoms of citizens in management (Hrobova, 2010). In this definition, due regard has already been paid to the main purpose of public administration authorities' administrative activity, which is the implementation and protection of rights and freedoms of citizens.

However, controlling authorities in the area of taxation, in particular, the SFS offices that are vested with greater part of supervisory powers, as compared to other government authorities, in the course of their dayto-day operations, perform a number of specific actions that determine the essence and the scope of their administrative activity and map into the corresponding attributes (features).

As a critical provision, it's worthwhile to note the viewpoint of T. O. Mazelyk who used to point out controlling authorities as the subjects of administrative law participate in the following types of administrative legal relations: public administration; relations of administrative services; relations of public administration responsibility for unlawful actions or failure to act; relations of responsibility of the subjects of the society (individual and collective) for violation of the rules and the procedures established by public administration (Matselyk, 2010). Those particular groups of relations will characterize the types of the SFS offices' administrative activity as controlling authorities in the area of taxation.

The scientists did not address the issue of distinguishing the features of SFS offices' administrative activity of (just as the features of Ukraine's State Tax Service offices' and revenue and duties offices' administrative activity) and, therefore, we should turn to the existing finalization dedicated to administrative activity.

Thus, when mapping out the features of internal affairs offices' administrative activity, the researchers used to call their attention not only to public and authoritative character, regulatedness by the norms of administrative law, etc., but also due account for the peculiarities of operational situation, the possibilities of causing legal consequences or without causing such (V. V. Konopliov (Konopliov, 2006). From D. V. Pryimachenko's perspective, the characteristic features of the customs authorities' administrative activity include, in addition to those indicated above, such features as public character(carried out not for satisfaction of private, personal needs of those who are entrusted with it but for the benefit of "one" and "all"), inclusion of both law-making and law-enforcement activity, regularity, continuity, planning, reasonable combination of centralized management with direct (operational) management, subordination and controllability of administrative activity to the corresponding state institutions; professionalism, preventive character (Pryimachenko, 2007). The researchers of the problem as to selecting of the administrative activity features of the certain executive authority used to point out its definiteness according to competence, normative due process, regulatory character, internal organizational and external orientation, etc.

The characteristic features defined by V. V. Konopliov and D. V. Pryimachenko can be taken as a basis for determination of the SFS offices' administrative activity features. In this context, we should highlight such main (leading) features as regulatedness by the norms of administrative law and state power. However, to get a complete picture of the SFS offices' administrative activity bodies, its components should be considered.

In public administration literature, administrative activity is presented as asystem composed of the followingelements: planning, organization, HR management, management, coordination, reporting, budgeting (Public administration: glossary, Bakumenko V. D., Beznosenko D. O., Varzar I. M., under the editorship of V. M. Kniazieva, V. D. Bakumenko, 2002) (Derzhavne upravlinnia: slovnyk-dovidnyk, Bakumenko V.D., Beznosenko D. O., Varzar I. M. ta in., red. V. M. Kniazieva, V. D. Bakumenko, 2002 - in Ukrainian). However, some scholars object to this approach because it combines different levels of the public administration function generalization with the specific stages of its implementation. Thus, in the opinion of S. Kyrii, the following subsystems should be identified within the administrative activity system: institutional, institutionary, function-based, organizational, communication and HR-related (Kyrii, 2009).

Institutional subsystem is a set of public administration authorities and officials formalized on the basis of the laws of Ukraine, decrees of the President of Ukraine, resolutions of the Cabinet of Ministers of Ukraine and administrations of the corresponding levels of the government that carry out organizational and administrative functions of the state (Kyrii, 2009). Institutional system of the SFS offices' administrative activity is manifested in the levels of building up a management system to control the said offices.

Institutionary subsystem is a set of formal and informal rules that facilitate administrative activity or on the basis of which this activity is carried out. They can include regulated and informal interaction rules between subject and objects of public administration (Kyrii, 2009). Such rules for the SFS offices' administrative and other activities implementation are fixed by the regulation 
which establishes this authority's status and by other acts of the applicable law, governing the specific features for the implementation of the competence to exercise state control in the area of taxation. Among the rules above, we should highlight, in particular, implementation of the measures to prevent corruption and control over their implementation within the SFS Headquarters, its territorial offices; implementation of HR related function, arrangement of planning and financing work and accounting; provision of methodological support; public relations; arrangement of work related to staffing, storage, record keeping and use of archive documents; arrangement of informational and analysis support of the SFS and its activities automation; documentation management (Pro Derzhavnu fiskalnu sluzhbu Ukrainy: Postanova Kabinetu Ministriv Ukrainy vid 05/21/2014 - in Ukrainian) (On the State Fiscal Service of Ukraine: Resolution of the Cabinet of Ministers of Ukraine as of the $21^{\text {st }}$ of May 2014). In addition, Article 20 of the Tax Code of Ukraine (hereinafter - the TC of Ukraine) stipulates the rights of controlling authorities in their relations with taxpayers and government authorities and Article 21 stipulates obligations and responsibilities. Analysing the orders of the applicable law as to the rights of controlling authorities in the area of taxation (in particular, the SFS offices), it may be noted that the Ukraine SFS offices perform not just administrative activity but also financial and legal activities in the area of taxation. What is more, the latter is performed through enforcement, in particular, measures of financial and legal enforcement.

The function-based subsystem is a set of functions performed by the subjects of public administration in the process of administrative activity implementation. It includes main functions of public administration: planning, motivations, organization, control (Kyrii, 2009). Such functions of the DFS offices (controlling authorities) are set forth in Article 19-1 of the TC of Ukraine and they include: control over compliance with tax legislation, accuracy of accrual and duly payment of taxes and duties (obligatory payments) to the budgets, special-purpose funds, as well as non-tax revenues established by law; formation and maintenance of the State Register of Individual Taxpayers and other obligatory payments and the Uniform Individual Taxpayers and Legal Entities Data Bank; awarenessraising work among the taxpayers about the tax legislation; prevention of crimes and other offenses that fall within the authority of tax police in accordance with the legislation; their disclosure, suspension, investigation and legal proceedings on administrative violations, implementation of national tax policy, as well as the policy in the area of control over production and turnover of alcohol, alcoholic beverages and tobacco and a set of others functions provided for by the TC of Ukraine (Podatkovyi kodeks Ukrainy (red 01/01/2017): Zakon Ukrainy vid 02.12.201 - in Ukrainian) (Tax Code of Ukraine as amended on the $1^{\text {st }}$ of January 2017: Law of Ukraine as of the $2^{\text {nd }}$ of December 2010).

In view of the above functions performed by the SFS, it can be concluded that the administrative activity of the authorities indicated above is not just of human rights practices nature but also of law enforcement nature.

The organizational subsystem includes mechanisms for organization and implementation of administrative activities (Kyrii, 2009). As a part of administrative activity, Section II of the TC of Ukraine is dedicated to the administration of taxes and payments, which regulates the procedure with respect to the following: provision of tax advice (Chapter 3); ways of tax control implementation and tax control authorities (Chapter 5); taxpayer registration (Chapter 6); audits and types of audits (Chapter 8); taxpayers' tax debt repayment procedures (Chapter 9); types and procedures for application of sanctions for violation of tax legislation are fixed (Chapter 11). In addition, the procedure for imposition of administrative sanctions for violation of tax legislation is regulated by the Code of Ukraine on Administrative Offenses (hereinafter CUoAO) (Kodeks Ukrainy pro administrativni pravoporushennia: Zakon Ukrainy, 1984 in Ukrainian). Specific types of administrative activity are also regulated by the Laws of Ukraine "On Use of Cash Registers in Trade, Catering and Services" (Pro zastosuvannia reiestratoriv rozrakhunkovykh operatsii u sferi torhivli, hromadskoho kharchuvannia ta posluh: Zakon Ukrainy vid 06.07.1995), “On State Regulation of Production and Turnover of Ethyl Alcohol, Cognac and Fruit Spirits, Alcoholic Beverages and Tobacco" (Pro derzhavne rehuliuvannia vyrobnytstva i obihu spyrtu etylovoho, koniachnoho i plodovoho, alkoholnykh napoiv ta tiutiunovykh vyrobiv: Zakon Ukrainy vid 19.12.1995 in Ukrainian) and other regulatory acts.

At the same time, it should be noted that there are the scientific researches dedicated to financial and control law (Savchenko, 2017) that clarify specifically the nature of public financial control as a function of financial activity management and a final stage of the management process.

Communication subsystem is connected with the methods of information collection, analysis and processing in course of administrative activity implementation (Kyrii, 2009). Thus, Section II of the TC of Ukraine establishes the tax reporting filing procedure and the persons responsible for this filing (Chapter 2), the information and analysis support procedure for controlling authorities activities (Chapter 7). The HR-related subsystem is connected with a selection of highly-qualified personnel, work with personnel, with the establishment of the appropriate conditions for administrative activities (Kyrii, 2009). The fundamental principles of the SFS offices' employees are established in Section XVIII-1 of the TC of Ukraine 
(Podatkovyi kodeks Ukrainy (red 01/01/2017): Zakon Ukrainy vid 02.12.2010 - in Ukrainian) (Tax Code of Ukraine, as amended on the $1^{\text {st }}$ of January 2017; Law of Ukraine as of the $2^{\text {nd }}$ of December 2010). The SFS offices' procedure for service accession, career, service termination is established by the Law of Ukraine "On Public Service" (Pro derzhavnu sluzhbu: Zakon Ukrainy vid 10.12.2015 - in Ukrainian)

In general, all components of the administrative activity in the course of its implementation are interrelated and interdependent and, in their entirety, they form an integral dynamic system (Kyrii, 2009).

\section{Conclusion}

Conducted research allows drafting the following conclusions. The essence of theSFSoffices' administrative activity stems from the history of Tax Service establishment and it covers control, registration and law enforcement activities aimed at the implementation of National tax policy, fight against offenses in the area of taxation by the measures of administrative legal nature. On a large scale, this is of executive and administrative nature and under its specific lines, only the legislation provides for application of conciliatory, explanatory, contract procedures. It is for this reason that we can refer to the appropriateness of laying the emphasis on the public and service component of Ukraine's SFS offices administrative activity as the controlling authorities in the area of taxation.

\section{Discussion}

Existing theoretical insights dedicated to the issue of determining the essence of administrative activity, its types and lines come from its public and legal nature, executive and administrative nature, law enforcement nature (I. P Golosnichenko, Y. Y. Kondratiev, A. P. Koreniev, Y. M. Moiseiev, V. I. Olefir, Y. I. Rymarenko and others), and occasionally they are limited to its perceptions from the viewpoint of view of exercise of executive power (Y. O. Tikhomirov). Additionally, there are scientific papers that recognize the organizational nature of the administrative activity, which becomes apparent in the certain functions of government authorities (N. I. Zolotariova).

As compared to the existing scientific papers, when determining the essence of administrative activity, it is proposed to take into account logical and semantic connection between the activity indicated above and the tasks and the functions performed by a subject of public relations according to its administrative-legal status. The indicated above is directly concerned with the controlling authorities in the area of taxation, in particular, Ukraine's State Fiscal Service offices that in comparison with other controlling authorities have a wider range of powers to control that perform specific tasks and functions determining the specific nature of their management (administrative) activity.

This approach does not conflict with the characteristic of administrative activity from the standpoint of structural and functional component of public administration (S. L. Kyrii) that allowed to agree with existence of the elements of dynamic administrative activity system and extrapolate (expand) this approach to definition of the essence of the controlling authorities' management (administrative) activity in the area of taxation.

2. The article defines that the SFS offices' administrative activity is carried out in the following lines:

A) Depending on the type of administrative legal relations involving the SFS office or its officer: public administration (establishment, reorganization, liquidation of the SFS Regional Offices, issuance of management legislative acts of regulatory nature, etc.); relations of administrative services (taxpayer registration, accountants of settlement operations, cash registers, issuance of licenses, patents, certificates, provision of tax advice, etc.); relations of responsibility of public administration for unlawful actions or inaction (appeal of the SFS offices' decisions, actions or inaction by administrative or judicial procedure; taking disciplinary action against the SFS offices' employees); relations of the taxpayers' liability for violation of the rules and the procedures established by public administration (bringing administrative action against them, application of administrative enforcement measures);

B) Depending on the type of the procedure being performed: non-jurisdictional (issuance of regulatory and individual management acts, registration, licensing, patenting, issuance of certificates, provision of tax advice, processing of the citizens' applications and proposals, recruitment to the SFS offices, encouragement of the SFS offices' employees, etc.) and jurisdictional (processing of the citizens' complaints, taking disciplinary actions, instituting administrative actions, auditing, administrative enforcement measures).

However, the most common will be consideration of the SFS offices' administrative activities implementation in the following lines: external administrative (external) and internal organizational (internal). Externaladministrative (external) line of the SFS offices activity is connected with the performance of their state functions on the basis of administrative regulations. Internal organizational (internal) line is connected with the organization of the SFS offices' system functioning.

3. Performed analysis of the specific features as to legal regulation of the SFS offices' activity and the scholars' achievements, proved advisability of presenting the controlling authorities' administrative activity concept in the tax area of taxation as regulatory, governmental activity related to implementation of controlling, registration, law enforcement actions, as well as internal 
organization activities, that are regulated by the norms of administrative law and aimed at implementation of the National tax policy, the citizens' rights and their protection, fight against offences in the area of taxation and organization of the SFS offices functioning. This activity is largely of executive-administrative and public nature, and in its specific lines, the law provides for application of conciliatory, explanatory and contract procedures. The existence of the competence related to the implementation of such procedures allows detailing a public and service component of the SFS offices' administrative activity.

\section{References:}

Koreneva, A. P. (2003). Admynystratyvnaia deiatelnost orhanov vnutrennykh del. Chast obshchaia: uchebnik [Administrative activity of internal affairs offices. General part: a textbook]. Mosk. yuryd. yn-t MVD Rossyy, yzd-vo «Shchyt-M».

Rymarenko, Yu. I., Moiseiev, Ye. M., Olefir, V. I. (2008). Administratyvna (politseiska) diialnist orhanivvnutrishnikh sprav (Zahalna chastyna): pidruchnyk [Internal affairs offices' administrative (law enforcement) activity (general part)]. K.: KNT.

Kovaliv, M. V., Kisil, Z. P., Kataianov, D. P. (2009). Administratyvna diialnist: navch. posib [Administrative activity: Textbook]. K.: Legal Unity.

Aliiev, R. V. (2009). Administratyvna diialnist kryminalno-vykonavchoi inspektsii shchodo osib, zvilnenykh vid vidbuvannia pokarannia $\mathrm{z}$ vyprobuvanniam [Administrative activity of corrective services with respect to the persons released from penalty on probation]. Avtoref. dys. ... kand. yuryd. nauk: spets. 12.00.07. Nats. un-t bioresursiv i pryrodokorystuvannia Ukrainy.

Bandurka, O. O. (2005). Upravlinnia derzhavnoiu podatkovoiu sluzhboiu v Ukraini: orhanizatsiino-pravovi aspekty: monohrafiia [Management of the State Tax Service in Ukraine: organizational and legal issues: monograph]. Kharkiv: Nats. universytetu vnutr. Sprav. (in Ukrainian)

Bandurka, O. O. (2004). Derzhavna podatkova sluzhba v Ukraini: systema, pravovyi status, modernizatsiia: monohrafiia [The State Tax Service in Ukraine: system, legal status, modernization: monograph]. Kh.: Vyd-vo NUVS. (in Ukrainian)

Bakhrakh, D. N. (2000). Admynystratyvnoe pravo Rossyy: ucheb. dlia vuzov [Administrative law of the Russian Federation: textbook for Higher Education Institutions]. M.: Yzd-vo NORMA (Yzdat. hruppa NORMA-YNFRA. $\mathrm{M})$. (in Russian)

Bachylo, Y. L. (2001). Ynformatsyonnoe pravo: uchebnyk [Information law: textbook]. SPb.: Yuryd. tsentr Press. (in Russian)

Bieliakov, K. I. (2008). Informatyzatsiia v Ukraini: problemy orhanizatsiinoho, pravovoho ta naukovoho zabezpechennia: monohrafiia [Development in Ukraine: challenges of organizational, legal and scientific support: monograph]. K.: KVITs. (in Ukrainian)

Bytiak, Y. P. (1999). Admynystratyvnoe pravo Ukrayni: obshchaia chast: ucheb. posob. [Administrative law of Ukraine: general part: textbook]. Kh. (in Russian)

Halunko, V. V. (2011). Napriamy administratyvnoi reformy v Ukraini [Lines of administrative reform in Ukraine]. Finansove pravo, 1, 199-205.

Holoborodko, D. V. (2009). Administratyvna diialnist orhaniv vnutrishnikh sprav shchodo protydii nelehalnii mihratsii [Internal affairs offices' administrative activity as to counteracting illegal migration]. Avtoref. dys. ... kand. yuryd. nauk. DDUVS. Dnipropetrovsk. (in Ukrainian)

Holovach, A. V. (2011). Kerivnyk v orhanakh Derzhavnoi podatkovoi sluzhby: administratyvno-pravovyi status: monohrafiia [Manager with the Offices of the State Tax Service: administrative and legal status: monography]. Kh.: Zolotamylia. (in Ukrainian)

Holosnichenko, I. P. (2005). Administratyvne parvo Ukrainy: osnovni poniattia [Administrative law of Ukraine: fundamental concepts]. K.: HAN. (in Ukrainian)

Hrobova, V. P. (2010). Administratyvnyi aspect derzhavnoho upravlinnia [Administrative aspect of pubic administration]. Aktualni problem prava: teoryia i praktyka. Sbornyk nauchnykh trudov, 18, 298-304.

Husarov, S. M. (2009). Administratyvno-yurysdyktsiina diialnist orhaniv vnutrishnikh sprav [Internal affairs offices' administrative and jurisdictional activity]. Dys. na zdobuttia nauk. stupenia doktor yuryd. nauk: spets. 12.00.07 "Administratyvne pravo i protses; finansove pravo; informatsiine pravo".

Bakumenko, V. D., Beznosenko, D. O., Varzar, I. M. ta in. (2002). Derzhavne upravlinnia: slovnyk-dovidnyk [Public administration: glossary]. K.: UADU. (in Ukrainian)

Dzisiak, O. P. (2002). Pravovyi status mistsevykh orhaniv derzhavnoi podatkovoi sluzhbyv Ukraini [Legal status of local state tax service offices in Ukraine]. Avtoref. dys.. na zdobuttia naukovoho stupenia kandydata yurydychnykh nauk: spets. 12.00.07 - teoriia upravlinnia; administratyvne pravo i protses; finansove pravo. Kharkiv. (in Ukrainian) Zarosylov, V. O. (2002). Porivnialnyi analiz administratyvnoi diialnosti militsii Ukrainy ta politsii zarubizhnykh krain (Velykobrytanii, SShA, Kanady ta Frantsii) [Comparative Analysis of the Ukrainian and Foreign Countries Police Administrative Activity (the UK, the USA, Canada and France)]. Dys. kand. yuryd. nauk: 12.00.07. Nats. akad. vnutr. Sprav. (in Ukrainian) 
Zolotarova, N. I. (2011). Spivvidnoshennia vykonavchoi vlady ta administratyvnoi diialnosti [Corelation of executive power and administrative activity]. Visnyk Natsionalnoho tekhnichnoho universytetu «KPI», 1(9), 45-54.

Kyrii, S. L. (2009). Administratyvna diialnist yak strukturno-funktsionalnyi komponent derzhavnoho upravlinnia [Administrative activity as a structural and functional component of public administration]. Derzhavne upravlinnia ta mistseve samovriaduvannia, 1(1).

Koval, L. V. (1998). Administratyvne pravo Ukrainy: kurs lektsii [Administrative law of Ukraine: course oflectures]. K.: Osnovy. (in Ukrainian)

Kodeks Ukrainy pro administratyvni pravoporushennia (1984). Zakon Ukrainy. Vidomosti Verkhovnoi Rady URSR [Code of Ukraine on Administrative Offences: the Law of Ukraine. Bulletin of the Supreme Soviet of the Ukrainian SSR]. № 51. Art. 1122.

Konoplov, V. V. (2006). Upravlinski rishennia v administratyvnii diialnosti orhaniv vnutrishnikh sprav: sutnist ta orhanizatsiino-pravovi pytannia pidhotovky i pryiniatti: monohrafiia [Management decisions in internal affairs offices' administrative activity: essence and organizational and legal matters for preparation and making: monograph]. Simferopol: Krymskoho yurydychnoho instytutu KhNUVS, VDMV “Tavriia”. (in Ukrainian)

Konstytutsiia Ukrainy vid 28.06.1996 No.254k/96-VR. Vidomosti Verkhovnoi Rady Ukrainy. 1996. No. 30 (23.07.96). Art. 141. (in Ukrainian)

Kulish, A. M. (2003). Orhanizatsiino-pravove zabezpechennia statusu pratsivnykiv podatkovoi militsii Ukrainy [Organizational and legal provision of the Ukraine's Tax Police Officers status]. Dys. na zdobuttia naukovoho stupenia kandydata yurydychnykh nauk: spets. 12.00.07 - teoriia upravlinnia; administratyvne pravo i protses; finansove pravo. Natsionalnyi universytet vnutrishnikh sprav. Kharkiv. (in Ukrainian)

Malynovskyi, V. Y. (2005). Slovnyk terminiv i poniat z derzhavnoho upravlinnia [Glossary of terms and notions on public administration]. Tsentr spryiannia instytutsiinomu rozvytku derzhavnoi sluzhby. K. (in Ukrainian)

Marchenko, B. M. (2009). Administratyvna diialnosti Derzhavnoi prykordonnoi sluzhby Ukrainy [Administrative activity of the State Border Guard Service of Ukraine]. Avtoref. dys. na zdobuttia nauk. stupenia kand. yuryd. nauk: spets. 12.00.07 "Administratyvne pravo i protses; finansove pravo; informatsiine pravo". Dnipropetrovsk. (in Ukrainian)

Marchenko, V. B. (2009). Administratyvno-pravove rehuliuvannia u sferi spravliannia podatkiv [Administrative and legal regulation in the area of tax collection]. Dys. ... kand. yuryd. nauk: 12.00.07. NUDPSU. Irpin. (in Ukrainian)

Matselyk, T. O. (2005). Administratyvnyi prymus v diialnosti orhaniv derzhavnoi podatkovoi sluzhby Ukrainy [Administrative enforcement in the course of the Ukraine's State Tax Service Offices Administrative Activity]. Dys. ... kand. yuryd. nauk: 12.00.07. Nats. akad. derzh. Podatkovoi sluzhby Ukrainy. Irpin. (in Ukrainian)

Matselyk, T. O., Kolpakov, V. K. (2010). Predmet administratyvnoho prava: onovlennia paradyhmy [Subject of administrative law: paradigm updating]. Pravo Ukrainy, 8, 110-115.

Mytnyi kodeks Ukrainy vid 13.03.2012 No.4495-VI. Ofitsiinyi visnyk Ukrainy, 2012, No. 32 (04.05.2012), Art. 1175. (in Ukrainian)

Novytskyi, A. M. (2012). Pravovi osnovy formuvannia instytutiv informatsiinoho suspilstva v Ukraini: teoriia i praktyka [Fundamental legal principles for establishment of information society institutions in Ukraine: theory and practice]. Avtoref. dys. na zdobuttia naukovoho stupenia kandydata yurydychnykh nauk: spets. 12.00.07 administratyvne pravo i protses; finansove pravo; informatsiine pravo. Natsionalnyi universytet DPS Ukrainy. (in Ukrainian)

Podatkovyi kodeks Ukrainy (red. z 01.01.2017): Zakon Ukrainy vid 02.12.2010 No. 2755-VI. Vidomosti Verkhovnoi Rady Ukrainy. 2011. No. 13 / No. 13-14, No. 15-16, No. 17. P. 556. Art. 112. (in Ukrainian)

Pryimachenko, D. V. (2007). Administratyvna diialnist mytnykh orhaniv u sferi realizatsii mytnoi polityky derzhavy [Customs offices' administrative activity in the area of national customs policy implementation]. Dys. na zdobuttia nauk. stupenia doktora yurydychnykh nauk: spets. 12.00 .07 - administratyvne pravo i protses; finansove pravo; informatsiine pravo. Natsionalnyi universytet derzhavnoi podatkovoi sluzhby Ukrainy. Irpin. (in Ukrainian)

Pro vnesennia zmin do Hospodarskoho protsesualnoho kodeksu Ukrainy, Tsyvilnoho protsesualnoho kodeksu Ukrainy, Kodeksu administratyvnoho sudochynstva Ukrainy ta inshykh zakonodavchykh aktiv: Zakon Ukrainy vid 03.10.2017 № 2147-VIII. Vidomosti Verkhovnoi Rady Ukrainy. 2017. № 48 (01.12.2017). Art. 436. (in Ukrainian) Pro derzhavne rehuliuvannia vyrobnytstva i obihu spyrtu etylovoho, koniachnoho i plodovoho, alkoholnykh napoiv ta tiutiunovykh vyrobiv: Zakon Ukrainy vid 19.12.1995 No. 481/95-VR. Vidomosti Verkhovnoi Rady Ukrainy. 1995. No. 46 (14.11.95). Art. 345. (in Ukrainian)

Pro derzhavnu sluzhbu: Zakon Ukrainy vid 10.12.2015 No. 889-VIII // Vidomosti Verkhovnoi Rady Ukrainy. 2016. No. 4 (22.01.2016). Art. 43. (in Ukrainian)

Pro Derzhavnu fiskalnu sluzhbu Ukrainy: Postanova Kabinetu Ministriv Ukrainy vid 21.05.2014 № 236. Ofitsiinyi visnyk Ukrainy. 2014. № 55 (18.07.2014). Art. 1507. (in Ukrainian)

Pro zastosuvannia reiestratoriv rozrakhunkovykh operatsii u sferi torhivli, hromadskoho kharchuvannia ta posluh: Zakon Ukrainy vid 06.07.1995 No. 265/95-VR. Vidomosti Verkhovnoi Rady Ukrainy. 1995. № 28 (11.07.95). Art. 205. (in Ukrainian)

Pro zakhody shchodo vprovadzhennia Kontseptsii administratyvnoi reformy v Ukraini: Ukaz Prezydenta Ukrainy vid 22.07.1998 № 810/98. Ofitsiinyi visnyk Ukrainy. 1999. № 21 (11.06.99). Art. 943. (in Ukrainian) 
Redkous, V. M. (2008). K voprosu o poniatyy admynystratyvnoi deiatelnosty orhanov natsyonalnoi bezopasnosty hosudarstv-uchastnykov SNH [On the issue of national security authorities' administrative activity concept of the CIS member-states]. Pravo y hosudarstvo: teoryia i praktyka, 6(42), 103-109.

Savchenko, L. A. (2017). Finansovo-kontrolne pravo: stanovlennia ta rozvytok: monohrafiia [Financial and auditing law: establishment and development]. K.: Yurinkom Inter. (in Ukrainian)

Servatiuk, L. V. (2008). Administratyvno-yurysdyktsiina diialnist orhaniv Derzhavnoi prykordonnoi sluzhby Ukrainy [Administrative and jurisdictional activity of the Office of the State Border Guard Service of Ukraine]. Dys. ... kand. yuryd. nauk : spets. 12.00.07. K.: NUVSU. (in Ukrainian)

Teremetskyi, V. I. (2012). Zahalna kharakterystyka elementiv struktury podatkovykh pravovidnosyn [General Characteristic of tax legal relations structure]. Visnyk Vyshchoi rady yustytsii, 1(9), 175-188.

Tylchyk, V. V. (2011). Administrative and Legal Mechanism for Tax Disputes Settlement: Abstract of a thesis for PhD in Law Degree: Specialty 12.00.07 - Administrative Law and Process; Financial Law; Information Law / Vyacheslav V. Tylchyk; National University of the State Fiscal Service of Ukraine. Irpin.

Tylchyk, V. V. (2011). Administratyvno-pravovyi mekhanizm rozviazannia podatkovykh sporiv [Administrative and legal mechanism for tax disputes settlement]. Avtoref. dys. na zdobuttia naukovoho stupenia kandydata yurydychnykh nauk: spets. 12.00.07 - administratyvne pravo i protses; finansove pravo; informatsiine pravo. Natsionalnyi universytet DPS Ukrainy. Irpin. (in Ukrainian)

Tykhomyrov, Y. A. (2005). Admynystratyvnoe pravo y protsess: polnii kurs [Administrative law and process: full course]. M.: Yzdanye h-na Tykhomyrova M. Y. (in Russian)

Uhrovetskyi, O. P. (2009). Systema opodatkuvannia v Ukraini: stanovlennia, administruvannia, reformuvannia: monohrafiia [Taxation system in Ukraine: establishment, administration, reforming: monograph]. Kh.: Zolota mylia, 2009. (in Ukrainian)

Usenko, Y. A. (2011). Pravove rehuliuvannia protsedur vyrishennia podatkovykh sporiv: monohrafiia [Legal regulation of tax disputes settlement procedures: monograph]. Kh.: Pravo. (in Ukrainian) 